\title{
A study on the agricultural research scientists' knowledge in the use of internet resources
}

Folitse, Benjamin Yao $\measuredangle$

Council for Scientific and Industrial Research-Institute for Scientific and Technological Information (CSIR-INSTI), Ghana (folitse62@yahoo.com)

\section{Osei, Simon Kwame}

Council for Scientific and Industrial Research-Institute for Scientific and Technological Information (CSIR-INSTI), Ghana (skosei@yahoo.co.uk)

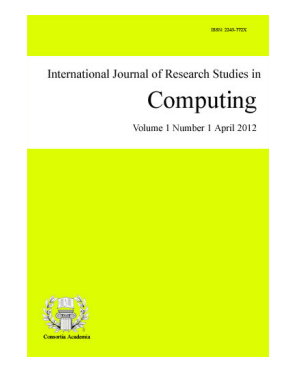

ISSN: 2243-772X Online ISSN: 2243-7797

OPEN ACCESS

Dzandu, Lucy Payne

Council for Scientific and Industrial Research-Institute for Scientific and Technological Information (CSIR-INSTI), Ghana (lucydzandu@yahoo.com)

\section{Obeng-Koranteng, Grace}

Council for Scientific and Industrial Research-Institute for Scientific and Technological Information (CSIR-INSTI), Ghana (graciarabeng@yahoo.com)

\section{Abstract}

The study examined the Research scientists' knowledge in the use of Internet resources for research in the Council for Scientific and Industrial Research (CSIR), Ghana. A quantitative research approach was adopted for the study, using a survey as research method. A random sampling technique was used to select 109 agricultural research scientists for the study. Data were collected through the use of a structured questionnaire. A total of 98 cases were analyzed which represented $89.9 \%$ of the total sample. The data were subjected to frequencies, percentages, means, standard deviation, Pearson's product-moment correlation (r) and multiple regression. The results showed that most researchers acquired computer knowledge without undergoing formal training in the use of the Internet. Mostly they learnt through self-development. The researchers used the Internet mostly for research purposes. The study therefore recommended that various institutes should acquire more bandwidth for their Internet connections to accommodate more computers and to improve the Internet speed. Internet networks must be active and continuously sustained in order to make this valued resource effective in all agricultural research institutes.

Keywords: research scientist; agricultural research institutes; internet resources; libraries; Ghana 


\section{A study on the agricultural research scientists' knowledge in the use of internet resources}

\section{Introduction}

Singh and Prasad (2013) opined that in the fast emerging information explosion, it is very difficult to access particular information without wasting time. The electronic resources give the solution and the users are attracted to electronic resources because of its great potential in facilitating the search of required information quickly. Vast e-resources are available in agriculture, and can be accessed in libraries and information centers which provide information to research scientists. In agricultural research, some of the important electronic resources like electronic journals, online databases, abstracts, e-books, online catalogues, directories, home pages of the institutes and organizations among others, are available, which are very useful and frequently used by agricultural scientists.

The Internet has been described as information super highway or information infrastructure to emphasize the expectation that it would transform the way information is created, manipulated, stored, retrieved, transferred and utilized (Ehikhamenor, 2003). The technology offers new opportunities for rapid communication and access to information worldwide as it is increasingly being used by all sectors of the society. This has made the resources of the world more accessible to ordinary people all over the world. Thus, the Internet has the capacity to provide an enabling environment and resources for research scientists in the CSIR to overcome the barriers of communication and collaboration.

The Internet also provides users with the means of carrying out research online by acting as the main engine for exchanging information especially among researchers. The Internet is capable of leading agricultural research scientists to exploit opportunities in their fields of research (Mani 2007). The use of the Internet for the exchange of research materials gives rise to the concept of electronic resource sharing which had reduced the shortage of information resources and consequently increased the output of research publications (Olalude, 2007). This is supported by Ng'etich (2003) who asserted that electronic publishing on the Internet has provided a greater opportunity for scholars and researchers to publish and present their ideas and research findings. Also, the Internet has provided an opportunity for researchers to have better access to each other and as tool to facilitate research (Ojedokun \& Owolabi, 2003; Oketunji, 2001). The Internet has provided researchers, individuals, and their institutions with an opportunity to present their ideas and research findings.

In order to achieve the objectives for which agricultural research institutes were established, management of each of the Agricultural Research Institutes saw the need to establish a library so as to provide information resources and services that could meet the information needs of the agricultural scientists. These libraries are invariably referred to as either special or research libraries. According to Edoka in Bitagi (2014), these libraries exist to further the research activities of their sponsoring organizations and provide information resources and services which are of direct relevance to the interest and activities of the institute. It therefore, becomes imperative that, the libraries must perform specific functions such as provision of comprehensive and balanced information resources and services relevant to all fields of specialization of the institutes, produce and disseminate current awareness services based on the profiles of each scientist and provide needed information as quickly and precisely as possible in order to save the time of the user.

Use of information resources by the agricultural research scientists in Ghana has to do with the extent to which information resources in all formats are actually put to use in order to carry out research in various aspects of agricultural development. This is with the view to improve and increase agricultural production to meet the food and industrial needs of Ghanaians and organizations. It will also help to minimize and or possibly eliminate importation of such products. A preliminary investigation by these researchers revealed that the primary 
objectives for which the agricultural research institutes in Ghana and their libraries were established, have not been adequately met. It seems Ghana cannot feed its teeming population without resorting to importation. Similarly, it was observed that most farmers were still practicing traditional methods of farming and using seeds derived from previous harvests.

From these revelations, the questions to be asked are: What are the demographic, work and internet use background of research scientists within the CSIR? Do agricultural scientists use Internet resources in research? What are the Internet knowledge levels of the agricultural research scientists? The answers to these questions constitute an information gap. It is in view of these that the study seeks to investigate the knowledge of agricultural research scientists in the use of Internet resources for research in the CSIR, Ghana.

\subsection{Objective of the study}

The general objective of the study was to assess the knowledge of agricultural research scientists in the use of Internet for research within the CSIR, Ghana.

\subsection{The specific objectives of the study were to:}

$>$ Describe the demographic characteristics of agricultural research scientists in the CSIR

$>$ Ascertain Internet knowledge level of agricultural research scientists

$>$ Find out the relationships between Internet knowledge level and demographic, work and Internet backgrounds of agricultural research scientists

$>\quad$ Define factors that predict Internet knowledge level of agricultural research scientists

$>\quad$ Examine challenges of using the Internet resources by agricultural research scientists

\subsection{Justification for the study}

In today's era, the number of researchers accessing internet has doubled up with the passing of time and the information provided on the web. Internet resources are the modern and basic way for the information access in many departments basically in teaching, learning and research. Researchers are depending more and more on the Internet resources for their various research activities. The present survey was, therefore, an attempt to assess agricultural research scientists' knowledge in the use of Internet resources for research in the Council for Scientific and Industrial Research (CSIR), Ghana. Internet resources are an indivisible part of today's research system. Information and knowledge are among the resources fundamental to the development process (CIDA, 2003). The scientific method of obtaining information and knowledge is through research. It means invariably that research is fundamental to any developmental process. Research constitutes the backbone of growth and development of sectors of a nation; be it economic, social, political, cultural, educational, agricultural, industrial or technological. Growth and development therefore, especially in Ghana must be based on research findings. For this reason, the findings from this study will give a clue to research scientists in the CSIR how Internet resources can aid them in their research activities to achieve optimum results with ease and speed. This will lead to growth and development in this sector, which will trigger development in all other sectors. Ghana will ultimately join the league of developed countries of the world.

\subsection{Scope of the study}

The study covers all agricultural research scientists in the research institutes of the CSIR. The opinions of the agricultural research scientists were sampled on knowledge in the use of internet resources for research in the Council for Scientific and Industrial Research (CSIR), Ghana. 


\subsection{Limitations of the Study}

Due to the wide spread of the research institutes in Ghana and time of the research, the study was restricted to only nine (9) out of the thirteen (13) research institutes of the CSIR. Therefore, the extent to which the findings of this study meet the need of all others is the limitation of this study.

\section{Literature review}

\subsection{Use of Internet resources by research scientists}

Use is the ability of using something for a purpose. It is the act of putting into action or services something that can be beneficial to someone. Omotayo (2010) defined use as the ability of researchers to adopt and adapt technologies to achieve a purpose or set goals. The concept of use is the ability of someone or group of persons to learn to apply knowledge to service (Rahman \& Ramzy, 2004). Similarly, Sethi and Panda (2012) defined Internet resources as resources in which information is stored electronically and are accessible through electronic systems and networks. Internet resources have been useful in the agricultural sector in different countries. According to Basonde and Pujar, (2008) use of Internet by research scientists is an important area of study in today's wired information environment. The Internet has become an important component in research institutions as it plays a pivotal role in meeting information needs of institutions and individuals. Basonde and Pujar, (2008) further stated that, the Internet makes it possible to access a wide range of information such as journals articles and papers from anywhere in the world. A study conducted by Singh and Bebi (2012) in India shows that agriculturalists used e-resources for research work, teaching and for updating themselves with current information. Generally, e-resources are important for teaching, learning, research and informational purposes.

It is known that for agricultural research to be effective current information is needed. Angello and Wema (2010) describe agricultural researchers' appreciation of the role played by e-resources in their day-to-day activities. Mtega, Dulle, Malekani, and Chailla, (2014) reported that, despite the potential of e-resources, the findings show that the usage of popular agricultural Internet resources among respondents is still low, possibly due to limited awareness. Limited ICT infrastructure, budgetary constraints and low information literacy levels have also resulted in inadequate access to and low usage of Internet resources. Because of the limited subscriptions made by institutes, most of the researchers and extension staff involved in the study relied on freely available and open access Internet resources. Access to and usage of Internet resources was influenced by individual factors including age, occupational category and the educational level (Mtega et al., 2014).

\subsection{Training on the use of Internet resources among agricultural scientists}

According to Sangayya (2002), Internet resources are feasible when there is sufficient training and awareness for the users. This training will need to be continued as technology of Internet resources keep on changing. According to Oduwole, (2004), users must be trained to be information literate in order to be able to recognize their needs for information, have ability to locate, evaluate and use needed information effectively, thus become independent users. Again, Margam (2017) was of the view that research scholars were not being systematically trained to effectively search the information on the Internet. Similarly, Bansonde and Pujar (2008) concluded in a study that, though Internet was being widely used by the research community of Shivaji University, there is the need to provide training on the use of Internet so that the researchers use the appropriate search tools and techniques than just relying on popular search engines and elementary search techniques to obtain information. Where they were taught the necessary skills, the learning was not reinforced. In the past, research scientists used standard reference books which could be assumed to be reliable.

This same assumption cannot be made about sources on the Internet. During actual on-line time, research scientists encounter a variety of obstacles. Research scientists get lost in cyberspace while engaged in nonlinear browsing and finding surfing the Internet to be addictive, time-consuming and unproductive because they do not 
know how to use appropriate search strategies (Margam 2017). They are inclined to take repeated side trips to sites unrelated to their research topic. While such nonlinear searching may be valuable as a form of individual learning, it is an ineffective way to conduct research. Unless research scholars are taught the skills necessary to support the construction of new meaning, they are likely to "skim along with little wisdom to show for their time and effort, but plenty of pages of info-glut" (McKenzie, 1995). In addition, when left to their own devices, research scientists are inclined to conduct simplistic searches. They type one or more keywords into the first white box they encounter in the first search engine or database they come across. In the context of simplistic searching, they also accept the system's defaults. Using this strategy in a small database is generally effective; however, in a "large database it tends to produce many irrelevant documents" (Barker, 1997). Gagan and Rakesh (2013) concluded in a study that, internet is being widely used by the research community of the University; there is a need to provide training on the use of internet so that the researchers use the appropriate search tools and techniques than just relying on popular search engines and elementary search techniques to obtain information.

\subsection{Benefits of accessibility and utilization of Internet resources}

According to $\mathrm{Ng}$ 'Tye and Chau (1995) one of the benefits of accessibility and utilization of electronic resources is increased efficiency in the research process at university. Similarly, Kaminer (1997) claimed that the use of electronic resources would enable scientists to be more productive in their research. Kaminer (1997) attributed this to the fact that, with electronic resources, access to information is faster, which invariably promotes efficiency in the research process and would definitely lead to an increase in research productivity. A review by Costa and Meadows (2000) showed that there is a positive association between the use of electronic resources and research productivity among scholars. Costa and Meadows (2000) carried out a survey to investigate the relationship between accessibility and use of electronic resources and research productivity among social scientists in Brazil. It was found that the responses regarding the effect of electronic resources on research productivity confirmed the existence of a positive relationship. Furthermore, the study revealed that research productivity of social scientists increases with accessibility and use of electronic resources, as respondents (economists and sociologists) in the survey agreed that electronic resources have a positive impact on research productivity. Heterick (2002) used a survey to determine the perceived effect of electronic resources on research productivity in American universities and found a high degree of perception of the impact of electronic resources on research productivity among the respondents. In view of this, Heterick (2002) concluded that electronic resources are invaluable tools for research in America. A similar survey conducted with professors at the University of Idaho (UI), Moscow, by Jankowska (2004) in Russia on the impact of the use of electronic resources on research showed that the vast majority of the respondents believed that electronic resources have brought about an increase in research productivity.

Mahajan (2006) explored the perception of researchers on the effect of accessibility and use of electronic resources on productivity at the Punjab University, Chandigarh, India, across three academic disciplines: science, social science, and the humanities. It was found that most scientists (99\%) agreed on the positive effect of electronic resources on research productivity, whereas about half the social scientists (50\%) disagreed, while all responses from researchers in humanities $(100 \%)$ were negative. The article, therefore, concluded that scientists were accessing and using electronic resources more than their counterparts in the social sciences and humanities. A study of the perceived effect of accessibility and use of electronic resources on research productivity by Vakkari (2008) showed a positive relationship between electronic resources and research productivity. Vakkari (2008) also found that the relationship varies from discipline to discipline.

\subsection{Impact of electronic resources on research and productivity}

Khan and Dominic (2012) conducted a survey to assess the perceived impact of electronic resources on the research productivity of academic staff in the engineering colleges of Moradabad, India. The results of the survey revealed that $50 \%$ of the respondents agreed on the productive impact of electronic resources on their 
research process. According to Nicholas, Williams, Rowlands, and Jamali (2010), electronic resources have made a tremendous impact on the research productivity of scholars in the United Kingdom, a view common in developed countries. In Africa, Mgobozi and Ocholla (2002) conducted a comparative study to investigate the relationship between the use of electronic journals by academic staff at the University of Natal and the University of Zululand in South Africa and their research productivity. According to the study, about 29\% indicated a correlation whereas $13 \%$ indicated no correlation and others were undecided. Badu and Markwei (2005) claimed that electronic resources are versatile tools for scholarly research in African universities. Their survey indicated that $64.2 \%$ of academics at the University of Ghana were in agreement that electronic resources impact positively on research productivity. When respondents were asked in the survey to rank the usefulness of electronic resources in research, 69.4\% of the respondents said they are "useful." Ojedokun and Owolabi (2003) conducted a study to determine the effect of the use of electronic resources on research productivity at the University of Botswana. The results showed that the respondents perceived that electronic resources are very useful in research and impacted positively on research productivity.

In Nigeria, Jimba and Atinmo (2000) found no significant association between accessibility and use of electronic resources on research productivity. In a study to investigate the impact of electronic resources on research productivity of scientists at Ten (10) Nigerian Universities, Ehikhamenor (2003) reported that very few respondents were of the opinion that electronic resources had a positive effect on their research productivity. In specific terms, $89.3 \%$ of the respondents strongly dis-agreed that access and use of electronic resources facilitates higher productivity in research. The study concluded that the extent to which access and use of electronic resources meets the research needs of scientists in Nigerian universities is minimal, and its contribution to increase research productivity is, therefore, not significant.

A study conducted by Ani, Ngulube, and Onyancha (2015) to explore the perceived effect of accessibility and utilization of electronic resources on research productivity of academic staff in Nigerian universities, found out that there was no significant perceived effect. They however share the assumption of a correlation between access to information, information use and research productivity. In an earlier study related by Ani et al. (2015) it was found that demographic variables had significant effect on accessibility and utilization of electronic resources. Bhatti and Hanif (2013) equally highlighted the usefulness of e-resources, online bibliographical services and databases for teaching, research and other purposes.

\subsection{Constraints to the use of Internet resources}

Despite the high level of enthusiasm in the use of electronic resources, social science researchers have identified obstacles in their usage of these resources. They are mainly identified as lack of networked computers to access databases, "availability, reliability and cost of the necessary equipment" (Harley, Henke, Lawrence, Miller, Percialli and Nasatir 2006). Another obstacle to the use of electronic resources is that they are not seen as being easily accessible. This is in contrast to an Internet search engine where a single keyword search could result in thousands of hits, no matter the topic. In the library, students have to choose a particular database and be more selective in the search words they use (Waldman, 2003). Watts and Ibegbulem (2006) examined some of the barriers to the use of electronic resources available at the medical library of the College of Medicine, University of Nigeria, Nsukka. Their findings revealed that lack of an adequate ICT infrastructure and affordable online access, absence of in-depth ICT skills and information searching skills among library staff and users are barriers to the use of electronic resources. In the same vein, Ondari-Okenwa (2004), Ashcroft and Watts (2005), Adomi (2005) and Oduwole and Sowole (2006) identified problems in the adoption and usage of ICT and electronic resources in Nigeria to include lack of adequate ICT skills among staff and users, low basic information literacy levels in the Nigerian population and prohibitive cost in developing countries to gain access to the Internet. The findings were corroborated by those of Salaam and Adegbore (2010) who studied Internet access and use by the students of private universities in Ogun State, Nigeria.

Several studies have shown that undergraduates use the library mostly as a place to study and make 
photocopies but they do not make great use of some of the available library services such as interlibrary loan, reference desk and its electronic resources (Whitmire, 2001). Many studies conducted in Africa have also identified the challenges of using electronic resources in the colleges and universities to include low ICT use skills, lack of adequate infrastructure for using electronic resources, especially epileptic power supply (Dadzie, 2009).

\section{Methodology}

\subsection{Research design}

A quantitative research approach was adopted for the study, using a survey as research method. Survey research is often used to assess thoughts, opinions, and feelings (Shaughnessy, Zechmeister, \& Jeanne, 2011). Survey research can be specific and limited, or it can have more global, wide spread goals. Survey research is one of the most important areas of measurement in applied social research. The broad area of survey research encompasses any measurement procedures that involve asking questions of respondents. Furthermore, survey design often considers past events as they relate to current conditions. Osuala (2005) noted that survey research studies use both large and small populations; selects study samples from the population to discover the relative incidence, distribution and interrelations of variables.

\subsection{Population for the study}

The population of the study was agricultural research scientists in nine research institutes of the study area that is, Animal Research Institute (ARI), Crop Research Institute (CRI), Forestry Research Institute of Ghana (FORIG), Food Research Institute (FRI), Oil Palm Research Institute (OPRI), Plant Genetic Resources Research Institute (PGRRI), Savanna Agricultural Research Institute (SARI), Soil Research Institute (SRI) and Water Research Institute (WRI).

Sample population - A descriptive survey design was adapted for the study. A random sampling technique was used to select 109 agricultural research scientists from the nine agricultural research institutes of the CSIR for the study. A total of 98 cases were analyzed which represented $89.9 \%$ of the total sample.

Data Collection - A librarian was selected from each of the nine (9) agricultural research institutes of the CSIR to collect data for the study. Data was collected between January and March 2016.

Data Analysis - Data collected was coded and entered into the Statistical Product and Service Solution (Version 21.0) computer software for analysis. Descriptive statistics were generated to clean data. To determine the demographic, work and Internet use background characteristics of agricultural research scientists in the CSIR, frequencies, percentages, means, and standard deviation were used. To analyze the second objective which was to determine agricultural research scientists' use of Internet resources in research, frequencies and percentages, were used. Similarly, to ascertain Internet knowledge level of agricultural research scientists, means, weighted mean and standard deviations were used. Furthermore to find out the relationships between Internet knowledge level and demographic, work and Internet backgrounds of agricultural research scientists, Pearson's product-moment correlation (r) was used. Finally, multiple regressions was used to define factors that predict Internet Knowledge level of agricultural research scientists.

\section{Results and discussion}

\subsection{Demographic characteristics of agricultural research scientists in the CSIR}

Table 1 presents the results of demographic characteristics of agricultural researchers in CSIR, Ghana. According to the results in Table 1,87.8\% agricultural research scientists in the CSIR are males and $12.2 \%$ are 
Folitse, B. Y., Osei, S. K., Dzandu, L. P., \& Obeng-Koranteng, G.

females. This suggests that there are more male agricultural research scientists than female agricultural research scientist across the surveyed institutes in the CSIR. This implies that male researchers dominated Agricultural Research Institutes in the CSIR. This finding supported the works of Ogunjobi and Fagbami (2012) that there were more male researchers than female researchers in Agricultural Research Institutes in Ibadan metropolis of Nigeria. Furthermore, the results revealed that majority of the researchers $(86.7 \%)$ are married and $3.1 \%$ are single; with $10.2 \%$ divorced. This implies that respondents in the study area assume some responsibility of their families.

Additionally, the results revealed $46.9 \%$ of agricultural research scientists in the CSIR-Ghana have between 2 and 3 dependents with ICT knowledge and $28.6 \%$ have one dependent with ICT knowledge. Also $13.3 \%$ of agricultural research scientists in the CSIR-Ghana had between 4 and 5 dependents with ICT knowledge and $11.2 \%$ had between 6 and 7 dependents. Similarly majority (75.5\%) of the respondents, were Master of Philosophy Degree (MPhil) holders while 24.5\% were holders of Doctor of Philosophy (PhD).This finding supports the work of Salau and Saingbe (2008) who found out that $71.10 \%$ of the agricultural researchers had post graduate degrees. This finding shows that they are highly knowledgeable and educated; therefore more contributions to agricultural research and development are expected from these agricultural researchers as they use internet resources for research activities. Also, more than half (68.4\%) of the respondents were between age $31-50$ years while $31.6 \%$ have their ages greater than 50 years in the CSIR, Ghana. The finding shows that most of the agricultural researchers are still in their active age; hence they are capable of using internet resources for agricultural research and development. Table 1 also shows that majority of the agricultural researchers (84.7\%) had been in the employment of the CSIR, Ghana between 18 and 19 years and $15.3 \%$ over 20 years. This shows that they are in the best position to supply useful information on research activities carried out in various Institutes.

\section{Table 1}

Demographic characteristics of agricultural research scientists in the CSIR

\begin{tabular}{|c|c|c|c|c|c|}
\hline Variables/Items & Frequency & Percentage & Variables/Items & Frequency & Percentage \\
\hline Gender & & & Education & & \\
\hline Male & 86 & 87.8 & Master's Degree & 74 & 75.5 \\
\hline Female & 12 & 12.2 & $\mathrm{PhD}$ & 24 & 24.5 \\
\hline Age & & & Number of Years CSIR & & \\
\hline $31-40$ & 39 & 39.8 & $5-7$ & 13 & 13.3 \\
\hline $41-50$ & 28 & 28.6 & $8-10$ & 20 & 20.4 \\
\hline $51-60$ & 31 & 31.6 & $11-13$ & 16 & 16.3 \\
\hline Marital Status & & & $14-16$ & 26 & 26.5 \\
\hline Single & 3 & 3.1 & $17-19$ & 8 & 8.2 \\
\hline Married & 85 & 86.7 & 20 above & 15 & 15.3 \\
\hline Divorced & 10 & 10.2 & & & \\
\hline Dependents with ICT & & & & & \\
\hline $0-1$ & 28 & 28.6 & & & \\
\hline $2-3$ & 46 & 46.9 & & & \\
\hline $4-5$ & 13 & 13.3 & & & \\
\hline $6-7$ & 11 & 11.2 & & & \\
\hline
\end{tabular}

Source. Field Survey Data, 2016.

\subsection{Internet Knowledge level of agricultural research scientists}

Researchers used the Internet resources for various purposes. Knowledge is a pre-requisite to effective use of internet resources, and therefore research scientists were asked to rate their internet knowledge. Table 2 shows that, all of the respondents of the survey said that they have knowledge of internet resources usage. Knowledge 
of agricultural research scientists in the use of internet resources for research is very essential in agriculture. According to Table 2 below, knowledge of research scientists in accessing emails $(x=4.63)$, attaching files $(x=4.50)$, sending files to individuals $(x=4.44)$, sending files to multiple recipients $(x=4.35)$, creating emails $(x=4.33)$, entering web address $(x=4.21)$, accessing e-journals (4.10), navigating pages on the internet $(x=4.07)$ and using search engines $(x=4.02)$ were very high among agricultural research scientists of the CSIR. The analysis presented above shows that there is a reasonable interest among agricultural research scientists in the use of the internet and its resources. Equally, downloading files from the internet $(x=3.96)$ accessing files: PDF, GIF, JPG ( $x=3.81)$, finding information ( $x=3.81)$, finding pages recently viewed $(x=3.71)$, using URL to locate website ( $\mathrm{x}=3.65)$, accessing databases/ libraries $(\mathrm{x}=3.63)$, listing favorites sites (3.32), joining discussion list/newsgroup $(\mathrm{x}=3.20)$ and using an online library catalogue $(\mathrm{x}=3.14)$ were moderately high among agricultural research scientists of the CSIR. This finding is a clear indication that agricultural research scientists within the CSIR have the knowledge to use internet resources for research activities in their various institutes. The Internet has been seen as an important part of research information source for most researchers. This is also an indication that the researchers had found the Internet to be a useful tool for their different research work.

Table 2

Internet search experiences of agricultural research scientists

\begin{tabular}{|c|c|c|}
\hline Internet Experiences & Mean & $\mathrm{SD}$ \\
\hline Accessing e-mails & 4.63 & 0.64 \\
\hline Attaching files/ pictures to e-mails & 4.50 & 0.72 \\
\hline Sending files/ text to individuals & 4.44 & 0.76 \\
\hline Sending files/ text to multiple recipients & 4.35 & 0.86 \\
\hline Creating e-mails & 4.33 & 0.75 \\
\hline Entering web address & 4.21 & 0.87 \\
\hline Accessing e-journals & 4.10 & 0.86 \\
\hline Navigating pages on the internet & 4.07 & 0.99 \\
\hline Using search engines & 4.02 & 1.07 \\
\hline Downloading files from the internet & 3.96 & 1.08 \\
\hline Accessing files (PDF,GIF,JPG) & 3.81 & 0.86 \\
\hline Finding information & 3.81 & 1.08 \\
\hline Finding pages you recently viewed & 3.71 & 1.02 \\
\hline Using URL to locate website & 3.65 & 1.13 \\
\hline Accessing databases/ libraries & 3.63 & 1.16 \\
\hline Listing favorites sites & 3.32 & 1.21 \\
\hline Joining discussion list/newsgroup & 3.20 & 1.23 \\
\hline Using an online library catalogue & 3.14 & 1.24 \\
\hline
\end{tabular}

Source. Field Survey Data, 2016. 5= Very High [VH], 4= High [H], 3 = Moderately High [MH], 2= Low [L], 1= Very low [VL].

\subsection{Relationships between Internet Knowledge level and demographic characteristics of agricultural research scientists}

A correlation table showing the relationship between Internet knowledge and demographic characteristics of agricultural research scientists is presented in Table 3. To establish the relationship between Internet knowledge and demographic characteristics, variables were estimated as follows: the overall Internet knowledge (IK) was estimated as composite mean (Y).

$$
\begin{aligned}
& Y=\text { Internet knowledge } \\
& X_{I}=\text { Sex }(1=\text { Male }, 0=\text { Female })
\end{aligned}
$$


$X_{2}=$ Age (Years)

$X_{3}=$ Marital status $(1=$ Not married, $0=$ Married $)$

$X_{4}=$ Educational Level (1= Master's degree, $\left.2=\mathrm{PhD}\right)$.

$X_{5}=$ Training $(1=$ Training, $0=$ No training $)$

$\mathrm{X}_{6}=$ Years of using internet

There were significant relationships between Internet knowledge and four (4) of the demographic characteristics (independent variables) except $\operatorname{sex}(\mathrm{r}=.040 ; p<.562)$ at 0.05 alpha level. The finding reflects that of Anandarajan, Simmers and Igbaria (2000) who found that sex had no relationship with Internet knowledge and Internet usage of US employees at their workplace. This implied that sex had no effect on whether agricultural research scientist used Internet or not. Similarly, there was a positive $(r=246 ; p>.001)$ correlation between marital status and Internet knowledge. This relationship was found to be low according to Table 3 . There were positive and significant relationships between agricultural research scientists' Internet knowledge and educational level $(\mathrm{r}=.665 ; p<.001)$, training $(\mathrm{r}=.580 ; p<.001)$ and years of using Internet $(\mathrm{r}=.652 ; p<.000)$. These positive relationships imply that educational level, training and years of using internet contribute to increase in Internet knowledge attained by agricultural research scientists'. Education plays a significant role in creating awareness and interest in innovations and also fundamental to understanding the usage and functionalities of the Internet (Eden \& Ofre, 2010). This implies that the kind of education, training and number of years of usage of internet by agricultural research scientists influenced their knowledge in the use of Internet resources for research in the Council for Scientific and Industrial Research (CSIR), Ghana. For example, the more training, higher education and years of internet usage by agricultural research scientists, the higher their knowledge in the use of Internet resources.

There was a significant relationship between agricultural research scientists Internet knowledge and age ( $r=-.486 ; p<.001)$. These findings support Rohde and Shapiro's (2000) assertion that level of Internet knowledge falls with age and years of experience. The younger agricultural research scientists use Internet more than veteran agricultural research scientists and for that matter have higher Internet knowledge than the aged agricultural research scientists.

Table 3

Relationships between Internet Knowledge level and demographic characteristics of agricultural research scientists

\begin{tabular}{lcccc}
\hline \multicolumn{1}{c}{ Independent variables } & $\begin{array}{c}\text { Correlation } \\
\text { Coefficient }(\mathrm{r})\end{array}$ & $\begin{array}{c}\text { Significance } \\
(\mathrm{p})\end{array}$ & $\begin{array}{c}\text { Type of } \\
\text { correlation }\end{array}$ & $\begin{array}{c}\text { Strength of } \\
\text { relationship }\end{array}$ \\
\hline Age $X_{1}$ & $-0.486^{* *}$ & 0.001 & Pearson & Moderate \\
Sex $X_{2}$ & 0.040 & 0.562 & Point Biserial & - \\
Marital status $X_{3}$ & $0.246^{* *}$ & 0.001 & Biserial & Low \\
Education level $X_{4}$ & $0.665^{* *}$ & 0.001 & Spearman & Substantial \\
Training $X_{5}$ & $0.580^{* *}$ & 0.001 & Biserial & Substantial \\
Years of using internet $\mathrm{X}_{6}$ & $0.652^{* *}$ & 0.000 & Pearson & Substantial \\
\hline
\end{tabular}

Source. Field Survey Data, 2016. **p< $0.01, * p<0.05$.

\subsection{Factors that Predict Internet knowledge level of Research Scientists}

Results in Table 4 show that years of Internet use $\left(X_{6}\right)$, training $\left(X_{5}\right)$, and educational level $\left(X_{4}\right)$ were the best predictors of Internet knowledge level of agricultural research scientists in the study. The adjusted R-squared of 
0.563 suggests that the six predictor variables explain about $56.3 \%$ of the variance/variation in Internet competency. Individually, years of Internet use is contributing $39.4 \%$ to the variation, while training contributes $10.7 \%$, and educational level $6.2 \%$. The contribution of years of Internet use, although, mirrors work done by Scheer (2011) on extension educators in U.S.A, the $39.4 \%$ of the variance or variation in Internet knowledge ascribed to how long educators in U.S.A had used Internet. Similarly, Yakubu (2011) had reported that training of extension workers in north-west zone of Nigeria in the use of Internet contributed $25 \%$ of variation in extension worker's competency level. In this case, education contributed only $6.2 \%$ in the variation.

\section{Table 4}

Stepwise Regression of Internet Competency of Research Scientists

\begin{tabular}{ccccccccc}
\hline Predictors & $\begin{array}{c}\text { Step of } \\
\text { Entry }\end{array}$ & $\begin{array}{c}\text { Beta } \\
\text { (standardized) }\end{array}$ & $\mathrm{R}^{2}$ & Adj $\mathrm{R}^{2}$ & $\begin{array}{c}\text { Adj } \mathrm{R}^{2} \\
\text { Change }\end{array}$ & S.E.E & F. Reg. & F. Sig* \\
\hline$X_{6}$ & 1 & 0.344 & 0.398 & 0.394 & 0.394 & 0.705 & 106.465 & 0.000 \\
$X_{5}$ & 2 & 0.208 & 0.479 & 0.472 & 0.107 & 0.658 & 73.512 & 0.000 \\
$X_{4}$ & 6 & 0.156 & 0.579 & 0.563 & 0.062 & 0.599 & 35.750 & 0.022 \\
\hline
\end{tabular}

Note. ${ }^{*} p<0.05$. Source. Field Survey Data, 2016.

The equation for the multiple linear regression model for Internet competency for extension delivery is provided as:

$\mathrm{Y}=2.787+.344 X_{6}+.208 X_{5}+.156 X_{4}+0 ; \mathrm{Y}=2.787$ if $\beta_{6}=\beta_{5}=\beta_{4}=0$.

Where; Dependent Variable $(\mathrm{Y})=$ Internet knowledge

\subsection{Constraints/challenges of using the internet resources}

The major constraints faced by the agricultural research scientists of the Council for Scientific and Industrial Research (CSIR) in using internet resources were the high cost of Internet usage (90.8\%), followed by slow internet connection (87.8\%) (Table 5). This result agrees with Ogunjobi and Fagbami (2012) and Arya (2015), that the most common problem faced by the internet users is that of slow internet access speed which takes a lot of their precious time to retrieve the relevant information. Epileptic power supply $(67.3 \%)$ was another constraint identified by the scientists and connectivity to many of the offices is very limited (64.3\%). This finding agreed with Udende and Azeez (2010); Olubanke (2012); Ivwighreghweta and Igere (2014) who found out that epileptic power supply and slow internet connections are the main constraint of scientists at Olabisi Onabanjo University using internet services and resources in their research activities. Other constraints mentioned by the agriculture research scientists were; "no Internet connectivity/access (61.2\%)", "high cost of equipment and broadband services (56.1\%)", "computers are not easily affordable (46.9\%)" and "inadequate information retrieval skills (36.7\%)" (Table 5). The results corroborate that of previous researchers such as Omotayo (2006) and Ogunkunle and Fomsi (2010) who carried a similar study among lecturers in tertiary institutions in Nigeria.

\section{Table 5}

Constraints/Challenges of using the Internet resources

\begin{tabular}{lcc}
\hline \multicolumn{1}{c}{ Variables } & Frequency & Percentage \\
\hline High cost of Internet usage & 89 & 90.8 \\
Poor internet speed/ slowness in accessing Internet & 86 & 87.8 \\
Epileptic power supply & 66 & 67.3 \\
Connectivity to many of the offices is very limited & 63 & 64.3 \\
No Internet connectivity/ access & 60 & 61.2 \\
High cost of equipment and broadband services & 55 & 56.1 \\
Computers are not easily affordable & 46 & 46.9 \\
Inadequate information retrieval skills & 36 & 36.7 \\
\hline
\end{tabular}

Source. Field Survey Data, 2016 


\section{Conclusion}

The importance of agricultural research scientists' knowledge in the use of Internet resources for research cannot be over emphasized. The agricultural research scientists of the CSIR believed that the internet resources have enhanced their research activities by generally holding very positive opinions on the contribution of internet to their job performance. That the internet resources has made it easier for them to find required information, increase their motivation to search for information, enabled quick communication of research findings and increased their level of exchange of information with colleagues. That the internet resources positively impacted on research activities of scientists and which is in agreement with the findings of Adogbeji and Toyo (2006) who reported that more than 90 percent of the sampled lecturers at Delta State University, Abraka, Nigeria agreed that the internet resources has added value to their academic pursuits in terms of quick access to research materials, including online journals. The major problem identified by the Agricultural Research Scientists' was high cost of Internet usage and the slowness of the internet connection at the various institutions.

\subsection{Policy Implications}

The study points to the fact that Agricultural Research Scientists in the CSIR needed information to carryout research in response to the research needs of their institutes and also respond to agricultural production challenges in Ghana. It is against this background that the use of Internet resources by Agricultural Research Scientists for research must not be discounted. The implication for policy, first of all, is that Agricultural Research Scientists from the CSIR must be trained in the use of Internet resources for Research effectively so that the actual benefits of policy of the CSIR may be realised. This empowerment may find greater expression in the implementation of capacity building programs that will lead to the acquisition of the relevant skills for enhanced research and delivery. There must be a sustained policy of continuous education and training for Agricultural Research Scientists in the use of Internet resources so that they will be abreast of the changing dynamics of agricultural research and delivery. The study showed that the Internet resources has made it easier for the agricultural research scientists to find required information, increased their motivation to search for information, enabled quick communication of research findings and increased their level of exchange of information with colleagues. Furthermore, while Agricultural Research Scientists' knowledge of sources of information for their research activities may not be in doubt, it is important that Librarians in the various research institutes create more awareness about the Internet resources.

\subsection{Recommendations}

Based on the findings of the study, the following recommendations were made to improve the use of the Internet resources by the agricultural research scientist:

$>\quad$ Research institutes of the CSIR Ghana, should acquire more bandwidth for their Internet connection to accommodate more computers and make the Internet fast.

$>\quad$ The management of the various institutes should increase the current state of Internet subscription for relevant Internet resources and online databases to enhance accessibility and utilization of Internet resources.

$>\quad$ The Librarians of the various institutes should strengthen their consorted effort for sustainability of subscription to more online databases to boost accessibility and utilization of Internet resources in the CSIR institutes.

$>\quad$ Orientation training programs should be organized by the Library staff of the various institutes of the CSIR for the agricultural research scientists at regular intervals so that they can improve their excellence or proficiency in the use of the Internet for research purposes. 


\section{References}

Adogbeji, O. B., \& Toyo, O. D. (2006). The impact of the internet on research: The experience of Delta State University, Nigeria. Library Philosophy and Practice, 8(2). Retrieved from http://digitalcommons.unl.edu/cgi/viewcontent.cgi?article=1084\&context=libphilprac

Adomi, E. E. (2005). Internet development and connectivity in Nigeria. Library Hi Tech, 39(3), $257-267$. https://doi.org/10.1108/00330330510610591

Anandarajan, M., Simmers, C., \& Igbaria, M. (2000). An exploratory investigation of the antecedents and impact of internet usage: An individual perspective. Behavior and Information Technology, 19(1), 69-85. https://doi.org/10.1080/014492900118803

Angello, C., \& Wema, E. (2010). Availability and usage of ICTs and e-resources by livestock researchers in Tanzania: challenges and ways forward, International Journal of Education and Development using Information and Communication Technology, 6(1), 53-65.

Ani, O. E., Ngulube, P., \& Onyancha, B. (2015). Perceived effect of accessibility and utilization of electronic resources on productivity of academic staff in selected Nigerian universities. SAGE Open, 5(4), 1-7. https://doi.org/10.1177/2158244015607582

Ashcroft, L., \& Watts, C. (2005). ICT skills for information professional in developing countries: Perspectives from a study of the electronic environment in Nigeria. IFLA Journal, 31(1), 6-12. https://doi.org/10.1177/0340035205052638

Arya, S. (2015). Internet and its use in the engineering colleges of Udaipur, Rajasthan, India: A Case Study. Research Journal of Library Sciences, 3(3), 8-12.

Badu, E. E., \& Markwei, E. D. (2005). Internet awareness and use in the University of Ghana. Information Development, 21, 260-268. https://doi.org/10.1177/0266666905060069

Barker, J. (1997). Searching the world wide web: Strategies, analyzing your topic, choosing search tools. Retrieved from http://www.lib.berkeley.edu/TeachingLib/Guides/Internet/strategies.html/\#AnalyzeTopic

Basonde, S. Y., \& Pujar, S. M. (2008). Use of internet by research scholars at Shivaji University, Kolhapur. Annals of Library and Information Studies, 55, 123-126.

Bhatti, R., \& Hanif, M. (2013). Impact of ICT on social science faculty members information usage at Bahauddin Zakariyya University. Library Philosophy and Practice. Retrieved from http://digitalcommons.unl.edu/libphilprac/928

CIDA. (2003). CIDA's strategy on knowledge for development through information and communication technology. Retrieved from http://www.acdi-cida.gc.ca/ict

Costa, S., \& Meadows, J. (2000). The impact of computer usage on scholarly communication among social scientists. Journal of Information Science, 26, 255-262. https://doi.org/10.1177/016555150002600405

Dadzie, P. S. (2009). E-Learning and e-library services at the University of Ghana: Prospects and challenges. Information Development, 25(3), 207-217. https://doi.org/10.1177/0266666909340791

Eden, M. B., \& Ofre, E. T. (2010). Reading and internet use activities of undergraduate students of the University of Calabar, Calabar, Nigeria. African Journal of Library, Archives \& Information Science, 20(1), 11-18.

Ehikhamenor, F. (2003). Internet resources and productivity in scientific research in Nigerian Universities. Journal of Information Science, 29, 35-48. https://doi.org/10.1177/016555150302900104

Gagan, S., \& Rakesh, P. (2013). Use of internet for research and educational activities by research scholars: A study of D.S.B. campus of Kumaun University-Nainital. International Journal of Management Studies, 4(2), 193-199.

Harley, D., Henke, J., Lawrence, S., Miller, I., Percialli, I., \& Nasatir, D. (2006). Use and users of digital resources: A focus on undergraduate education in the humanities and social science. Centre for Studies in Higher Education. UC Berkeley.

Heterick, B. (2002). Faculty attitudes toward electronic resources. Educause Review. Retrieved from https://net.educause.edu/ir/library/pdf/erm0248.pdf 
Folitse, B. Y., Osei, S. K., Dzandu, L. P., \& Obeng-Koranteng, G.

Ivwighreghweta, O., \& Igere, M. A. (2014). Impact of the internet on academic performance of students in tertiary institutions in Nigeria. Journal of Information and Knowledge Management, 45(2), 47-56.

Jankowska, M. A. (2004). Identifying university professors' information needs in the challenging environment of information and communication technologies. The Journal of Academic Librarianship, 30, 51-66. https://doi.org/10.1016/j.jal.2003.11.007

Jimba, S. W., \& Atinmo, M. I. (2000).The influence of information technology access on agricultural research in Nigeria. Internet Research: Electronic Networking Applications and Policy, 10, 63-71. https://doi.org/10.1108/10662240010312110

Kaminer, N. (1997). Scholars and the use of the Internet. Library \& Information Science Research, 19, $392-345$. https://doi.org/10.1016/s0740-8188(97)90024-4

Khan, S., \& Dominic, J. (2012). Use of internet by the faculty members of engineering colleges of Moradabad: A comparative study. ICAL: Library Services. Retrieved from http://crl.du.ac.in/ical09/papers/index_files/ical-95_124_278_1_RV.pdf

Mahajan, P. (2006). Internet use by researchers: A study of Panjab University, Chandigarh. Library Philosophy and Practice, 8(2). Retrieved from http://libr.unl.edu:2000/LPP/lppv8n2.htm

Mani, A. K. (2007). Availability and utilization of the Internet for academic activities in selected federal universities in Northern Nigeria (Master's thesis). Bayero University, Kano Nigeria.

Margam, M. (2007). Internet use by research scholars in university of Delhi, India. Library Hi Tech News, 24(8), 36-42. https://doi.org/10.1108/07419050710836036

McKenzie, J. (1995). Direct connect: Before net and after net. Multi Media Schools, 2(3), 6-8.

Mtega, W. P., Dulle F., Malekani, A. W., \& Chailla, A. (2014). The usage of e-resources among agricultural researchers and extension staff in Tanzania. Library and Information Research, 38(119), 47-66.

Mgobozi, M., \& Ocholla, D. N. (2002). A comparison of the use of electronic journals for the dissemination of scholarly information by the University of Natal and the University of Zululand. In T. Botha \& A. Kaniki (Eds.), Progress in library and information science in Southern Africa. Proceedings of the Second Biennial DISSA net Conference (pp. 29-45). Farm Inn, Pretoria, South Africa

Ng'etich, A. K. (2003). Old problem, new strategies: Internet as tool for research in Africa. Retrieved from http://www.codesria.org/Links/conferences/el_publ/ngetich.pdf

Nicholas, D., Williams, P., Rowlands, I., \& Jamali, H. R. (2010). Researchers' e-journal use and information seeking behaviour. Journal of Information Science, 36, 494-516. https://doi.org/10.1177/0165551510371883

Oduwole, A. A. (2004). Impact of internet use on agricultural research outputs in Nigerian Universities of agriculture. Library Hi Tech News, 21(6), 12-15. https://doi.org/10.1108/07419050410554843

Oduwole, A. A., \& Sowole, A. O. (2006). Utilisation and impact of the Essential Electronic Agriculture Database (TEEAL) on library services in Nigerian University of agriculture. Electronic Library Information System, 25(8/9), 361-167. https://doi.org/10.1108/00330330610669271

Ogunjobi, T. E., \& Fagbami, O. O. (2012). Use of the internet by researchers in agricultural research institutes in Ibadan, Oyo State. International Journal of Library and Information Science, 4(4), 52-56. https://doi.org/10.5897/IJLIS11.068

Ogunkunle, R. A., \& Fomsi, E. E. (2010). Internet literacy for research development among lecturers in tertiary institutions in Rivers State, Nigeria. Journal of Emerging Trends in Educational Research and Policy Studies, 1(2), 55-60.

Ojedokun, A. O., \& Owolabi, E. O. (2003). Internet access competence and the use of the internet for teaching and research activities by University of Bostwana Academic Staff. African Journal of Library and Information Science, 13(1), 43-53.

Oketunji, I. (2001). Libraries and Internet connectivity what benefits. In J. Lasis, O. K. Odunsanya, S. E. A. Sonaike, \& L. F. Osinulu (Eds.), Automation of cataloguing practices in Nigerian libraries (pp. 32-40). Ijebu-Ode: Nigerian Library Association, Cataloguing, Classification and Indexing Section.

Olalude, F. (2007). Utilisation of Internet sources for research by information professionals in sub-Saharan Africa. African Journal of Library, Archives and Information Science, 17(1), 53-58. 
A study on the agricultural research scientists' knowledge in the use of internet resources

Olubanke, M. B. (2013). The use of internet services and resources by scientists at Olabisi Onabanjo University, Ago Iwoye, Nigeria. Program, 47(1), 15-33. https://doi.org/10.1108/00330331211296295

Omotayo, B. O. (2006). A survey of Internet access and usage among undergraduates in an African University.

The International Information and Library Review, 38, 215-224.

https://doi.org/10.1080/10572317.2006.10762724

Omotayo, B. O. (2010). Access, use, and attitudes of academics toward electronic journals: A case study of Obafemi Awolowo University, Ile-Ife. Library Philosophy and Practice. Retrieved from http://digitalcommons.unl.edu/libphilprac/335

Ondari-Okemwa, E. (2004). Impediments to promoting access to global knowledge in sub-Saharan African. Library Management, 25(8/9), 361-375. https://doi.org/10.1108/01435120410562853

Osuala, E. C. (2005). Introduction to research methodology. Yola: Paraclete Publishers.

Rahman, R., \& Ramzy, H. (2004). Awareness and use of electronic information resources at the health science centre of Kuwait University. Library Review, 53(3), 150 -156. https://doi.org/10.1108/00242530410526556

Rohde, G. L., \& Shapiro, R. (2000). Falling through the net: Toward digital inclusion. A Report on Americans' access to technology Tools. New York: Guilford Press.

Salaam, M. O., \& Adegbore, A. M. (2010).Internet access and use by students of private universities in Ogun State, Nigeria. Library Philosophy and Practice. Retrieved from http://unllib.unl.edu/LPP/salaam-adegbore.htm

Salau, E. S., \& Saingbe N. D. (2008). Access and utilization of information and communication technologies (ICTs) among agricultural researchers and extension workers in selected institutions in Nasarawa State of Nigeria. Production Agriculture and Technology Journal, 4(2), 1-11.

Sangayya, S. S. (2001). Electronic library and information services: A case study. Paper presented at CALIBER-2001. University of Pune.

Sethi, B. B., \& Panda, K. C. (2012). Use of e-resources by life scientists: A case study of Sambalpur University, India. Library Philosophy and Practice (e-journal). Paper 681.Retrieved from http://digitalcommons.unl.edu/libphilprac/681

Shaughnessy, J., Zechmeister, E., \& Jeanne, Z. (2011). Research methods in psychology (9th Ed.). New York, NY: McGraw Hill.

Singh, K. P., \& Bebi, M. S. (2012). Use of e-journals by agricultural scientists: A case study of the ICAR libraries in Delhi. Library Herald, 50(2).

Singh, P. K., \& Prasad, H. N. (2013). Use of electronic resources: A study of Indian Agricultural Research Institute, New Delhi. International Journal of Information Research, 3(2), 141-168.

Udende, P., \& Azeez, A. L. (2010).(Internet access and use among students of the University of Ilorin, Nigeria. Journal of Communication and Media Research, 2(1), 33-42.

Vakkari, P. (2008). Perceived influence of the use of electronic information resources on scholarly work and publication productivity. Journal of the American Society for Information Science and Technology, 59, 602-612. https://doi.org/10.1002/asi.20769

Waldman, M. (2003). Freshmen's use of library electronic resources and self-efficacy. Information Research, $8(2)$. Retrieved from http://www.informationr.net/ir/8-2/paper150.html

Watts, C., \& Ibegbulem, I. (2006). Access to electronic healthcare information resources in developing countries: Experience from the medical library, College of Medicine, University of Nigeria. IFLA Journal, 32(1), 54-61. https://doi.org/10.1177/0340035206063903

Whitmire, E. A. (2001). Longitudinal study of undergraduate's academic library experiences. Journal of Academic Librarianship, 27(5), 379-385. https://doi.org/10.1016/S0099-1333(01)00223-3

Yakubu, D. H. (2011). Socio-economic factors affecting the adoption of ICTs by extension workers in the North-West zone of Nigeria (Master's Thesis). Usmanu Danfodiyo University, Sokoto, Nigeria. 
Folitse, B. Y., Osei, S. K., Dzandu, L. P., \& Obeng-Koranteng, G. 